\title{
Arbuscular Mycorrhizal and Endophytic (DSE) Association in the Dominant Grasses of Melghat Forest (Phase -I), India
}

\author{
${ }^{1}$ P. W. Deotare, ${ }^{2}$ S. P. Khodke, ${ }^{3}$ R. C. Maggirwar, ${ }^{4}$ S. K. Kharwade \\ 1,3,4 Mycorrhizal Biotechnology Lab, P.G. Department of Botany, \\ Shri Shivaji Science College, Amravati, (Maharashtra), India. \\ ${ }^{2}$ Vinayak Vidnyan Mahavidyalaya, Nandgaon(Kh.), Amravati, (Maharashtra), India. \\ Corresponding Author: dr.krekha@yahoo.com
}

\section{Manuscript Details}

Manuscript Submitted : 03/03/2019

Manuscript Revised : :10/03/2019

Manuscript Accepted : 10/03/2019

Manuscript Published : 15/03/2019

\section{$\underline{\text { Available On }}$}

https://plantaescientia.website/ojs

\section{Cite This Article As}

Deotare PW, SP Khodke, RC Maggirwar \& SK Kharwade (2019). Arbuscular Mycorrhizal and Endophytic (DSE) Association in the Dominant Grasses of Melghat Forest (Phase -I), India, Pla. Sci. 2019; Vol. 01 Iss. 06: 87-98. DOI: https://doi.org/10.32439/ps.vli06.87-98

\section{Copyright}

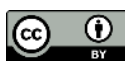

(c) The Author (s). 2019. Open Access This article is distributed under the terms of the Creative Commons Attribution 4.0 International License http://creativecommons.org/licenses/by/4.0/

\section{Indexed In}

Crossref, Index Copernicus International (ICI), Directory of Research Journal Indexing (DRJI), Scientific Indexing Services (SIS), CiteFactor,

\begin{abstract}
Investigations on arbuscular mycorrhizal fungi (AMF) and dark septate endophytic (DSE) association in some of the dominant grasses from Melghat forest (phase I) of Satpura terrain India, was carried out to examine their existence and symbiotic relationships with the host plants. This forest area was not surveyed earlier by anybody to evaluate the AMF status diversity hence it was decided to survey the buffer and core area. Rhizosphere soil of each sampled grass was analyzed for the AM fungal structures in the roots to study percent root colonization by AMF and AMF spore density in rhizospheric soils of respective samples. The composite soil sample was prepared for each site and used for physicochemical analysis by standard methods. In the first phase of the project, forty-eight dominant grass species from twenty-one different sites were collected along with roots and rhizospheric soil to find out AMF and DSE status of grasses. Both types of fungal associations was found in almost all the grass species collected during studies. All of them were found colonized by AMF hyphae along with moderate to poor development of mycorrhizal structures in roots. DSE colonization was also found in maximum forty-three species of grasses. Physicochemical characterization of all the soil samples were performed to find out its correlation with AM percent colonization and spore count. Mean AMF percent colonization was in between 1.33 to 52.85 and DSE in with 0.00 to 18.97. Viable AM spore count was in between 0 to 98 per $100 \mathrm{~g}$ of soil. Altogether four AMF genera with its thirty-nine-different species were isolated and identified. A database of indigenous AM species richness for Melghat forest has been generated to plan and design the future management practices for grasses establishment and development especially in burnt and overgrazed areas.
\end{abstract}

Keywords: Grasses of Melghat, AMF, DSE, Diversity, Melghat Forest. 


\section{INTRODUCTION}

Melghat forest is amongst the first nine tiger reserve declared and notified by the Indian government in 1974 as project tiger of Satpura terrain, spread in $2029 \mathrm{Km}^{2}$ area. The forest type is a southern tropical mixed dry deciduous with the dominance of finest teak (Tectona grandis Linn. f.). The forest is located at $21^{\circ} 26^{\prime} 45^{\prime \prime} \mathrm{N} 77^{\circ} 11^{\prime} 50^{\prime \prime} E$ of northern part of Amravati district of Maharashtra state, India. species (Wardle et al., 2004). Bellgard (1993); Schwab and Reeves (1981) concluded that arbuscular mycorrhizal fungi (AMF) are mainly found in upper layer of soil and occur in high quantity in rhizosphere area and establish symbiotic association in almost all-natural ecosystems (Brundrett, 1991). On the global basis, mycorrhizae occur in $83 \%$ dicot and $79 \%$ of monocot plants and in all the gymnosperms (Wilcox 1991). AMF is associated with the roots of plant

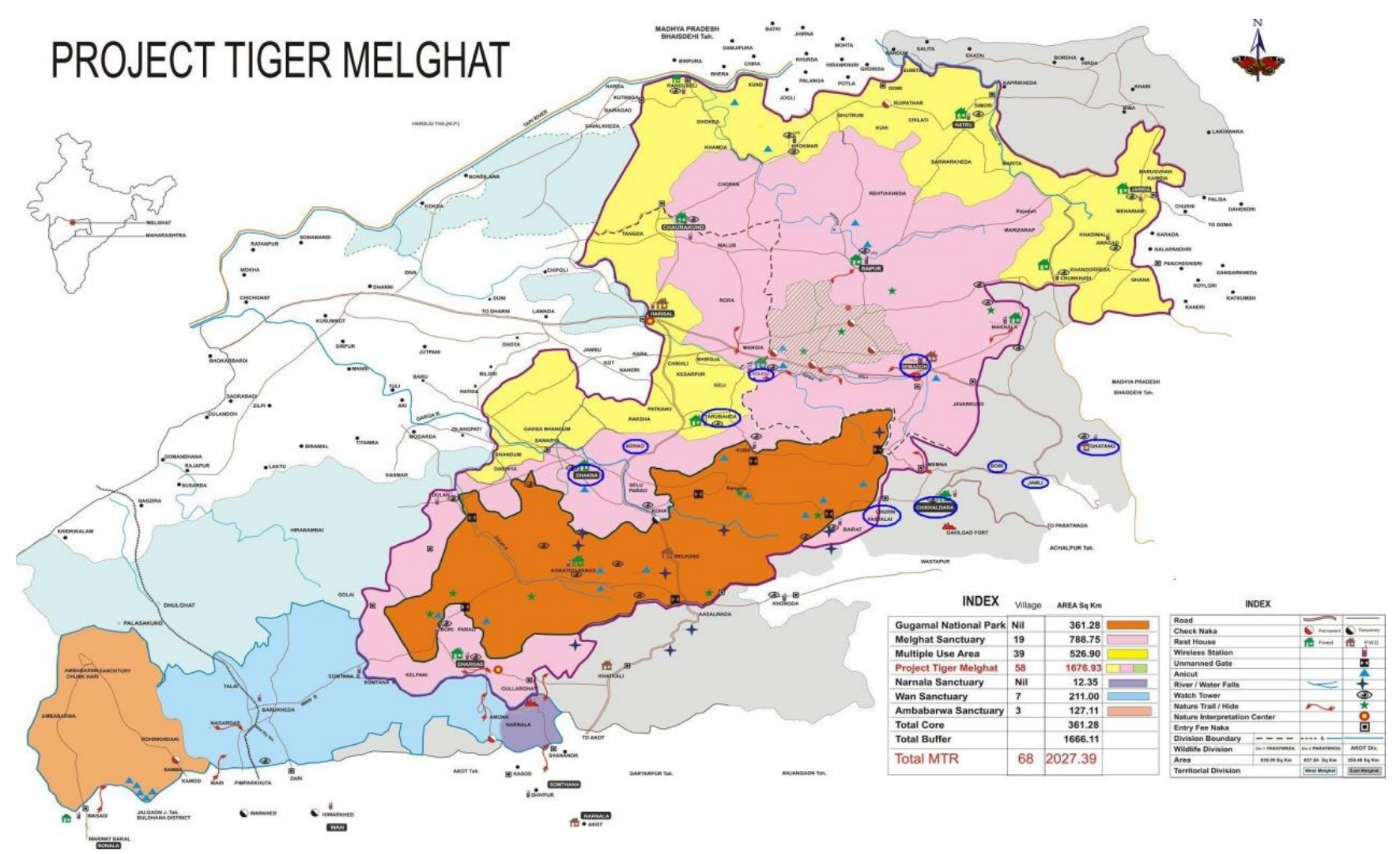

Map I: Study Area Map

Grasses are monocotyledonous flowering plants belonging to family Poaceae formerly known as Gramineae are distributed widely throughout the world. They are ubiquitously found in almost all type of habitats and are helpful for growth of all plant communities (Mitra and Mukherjee, 2005). They are used as forage for domestic and wild animals, birds and for soil conservation. The Grains of grasses are provided as staple food for human (Gould, 1968) which satisfy about $80 \%$ of human nutrient requirement (Stebbin, 1972). They also play an important medicinal role (Mitra and Mukherjee, 2005; Jeeva et al., 2006). Ecologically grasses are crucially important as their root system is very extensive and act as an effective soil binder (Skerman and Riveros, 1990); they consequently protect the erosion of banks of water tributaries (Saini et al., 2007).

Soil microbes are effectively responsible for the health and productivity of plants (Bloemberg and Lugtenberg, 2001), hence the high level of soil microbial community is highly responsible for maintenance of high diversity of plant taxa and becoming an integral part of it, they occur in most of the ecosystems like dense rain forest, grasslands, sand dunes, savannas, woodlands, arid and semi-arid regions and are most common in different zones of the world and widely found in temperate, tropical and arctic regions of the earth forming broad ecological range.

Many researchers extensively studied the occurrence of AMF in tropical forests and subtropical forests (Mosse 1973; Janos 1980, Bagyaraj et al., 2002). In India, distribution of AMF from semi-arid region was studied by Mukherji and Kapoor (1986); Rachel et al., (1989).

Like AMF, Dark Septate Endophytes (DSE) which forms septate hyphae and microsclerotial structure in cortical region of roots are also capable to form mutual association (Jumpponen, 2001) and are common microbial community in tallgrass prairies (Mandyam and Jumpponen, 2005; 2008) and highly compatible with grasses and act beneficial to plant health in drought condition. 
In the perusal of literature very scanty information is available about AMF and DSE association with grasses. The overall assessment of Melghat forest flora and fauna cannot be completed unless information available about this area is complete in all the respect. Therefore, the present investigation was undertaken to examine AMF and DSE relationship with dominant grasses of forest along with its colonization and diversity status of AM species in the Melghat forest for the first time.

\section{MATERIALS AND METHODS}

Studies were conducted in the Melghat forest of Satpura hill ranges from Amravati district, (Maharashtra), India. The forest is dry deciduous dominated by one of the best teak of India. The forest has rich biodiversity of different important medicinal plants along with various species of grasses. The grasses are considered to be a very important integral part of forest ecosystem and arbuscular mycorrhizae are one of the key components for the development and sustenance of forest ecosystems. In the first phase of survey, twenty-one different locations were selected for sampling. The samples were collected between September to December (2014). The photographic collection of grasses and its herbarium is maintained in the laboratory.

The top $2-3 \mathrm{~cm}$ of soil around each grass species were removed and rhizosphere soils along with root systems from $4-15 \mathrm{~cm}$ depth were collected in polyethene bags, labelled and brought to the laboratory for further processing. The soil and root samples in triplicate were maintained in refrigerator at $4^{\circ} \mathrm{C}$ to find out physicochemical properties of soil, AMF spore count and taxonomic status of isolated AM spore.

Wet sieving and decanting technique of Gerdemann and Nicolson (1963) was used for the spore extraction and for spore count the method given by Gaur and Adholeya (1994) was followed. Only viable spores were counted and picked up by needle using Carl Zeiss semi DV 4 stereo zoom microscope. The mean spore density was expressed as spores in 100g soil. Permanent slides of these spores were prepared using polyvinyl alcohol. The detailed photography of these spores was done by Tucsen camera attached to Carl Zeiss Primostar Trinocular compound microscope under 10, 40 and 100x objectives. Morphotaxonomic identifications of extracted spores were carried out using the manuals of Schenck and Perez (1990) and INVAM.

All the permanent slides are deposited in Mycorrhizal biotechnology lab of Shri Shivaji Science College, Amravati

\section{Data Analysis}

The standard deviation of means was calculated. Pearson correlation coefficients were computed for soil physicochemical properties with AMF spore count and colonization. Ecological measures of diversity to describe AMF communities includes spore count, species richness, relative abundance, isolation frequency, Shannon-Winer index of diversity, Evenness and Simpson's index of dominance were used.

\section{RESULTS}

The soil physicochemical characteristics of the study sites of phase-I (buffer area) is presented in Table no l. The soils were slightly acidic to alkaline in nature with $\mathrm{pH}$ ranged between 6.5 to7.8 and soil texture was mostly sandy clay loam. The range of other soil parameters such as EC ranged from 0.13 to $32.1 \mathrm{dsm}^{-1}$; phosphorus (P) 1.31 to $786.5 \mathrm{~kg} \mathrm{Ha}^{-1}$ whereas some sites were $\mathrm{P}$-deficient; potassium(K) 192.64 to $2723.84 \mathrm{~kg} \mathrm{Ha}$-1; Nitrogen (N) 109.76 to $517.44 \mathrm{~kg} \mathrm{Ha}{ }^{-1}$; \% Organic carbon 0.16 to 0.77 . The micronutrients like Copper $(\mathrm{Cu})$ ranged from 2.68 to 13.03 and Zinc (Zn) 0.52 to 4.23 ppm.

The site wise mean of AMF and DSE \% colonization was found in between 1.33 to 52.85 and 0 to $18.97 \%$ respectively. The mean of spore count of AMF ranged from 0 to 98 per $100 \mathrm{~g}$ of soil.

The grasses were collected from 21 different sites of phase-I and identified. In all 48 different grass species belonging to 37 genera were identified (Photo Plate-I) Highly dominant grasses from phase-I were found to be Aristida hystrix Thunb., nom. illeg., Arthraxon lanceolatus (Roxb.) Hochst., Dichanthium pertusum (L.) Clayton, Digitaria stricta Roth ex Roem. \& Schult., Setaria pumila (Poir.) Roem. \& Schult., Sporobolus tenuissimus (Mart. ex Schrank) Kuntze.

Intact viable AMF spores were isolated from all 21 sites of phase- I. In all $1430 \mathrm{AM}$ spores were extracted and identified from all the sites from $100 \mathrm{~g}$ soil of each site. As per morpho taxonomic characters 39 different AMF species belonging to 4 genera were recovered from different location (Table- 2 and Photo Plate-II). Amongst 39 AM fungal species, Glomus represented by 29 different species, Acaulospora with 5 species, Gigaspora with 4 species and only one species of Scutellispora. Glomus found to be the most dominant genus with $74.35 \%$ species population followed by Acaulospora $12.82 \%$, Gigaspora $10.25 \%$ and the least species that of Scutellispora with $2.56 \%$.

Investigations were also carried out to observe presence or absence and types of arbuscular and intraradical AM spores in individual grassroots (Photo Plate No. III)

Apart from different types of arbuscules, other AMF structures such as hyphal penetration and appressorium, vesicles, $\mathrm{H}$-connections and Y-junctions, hyphal coils, intraradical spores, extra-radical hyphae and spores have 
been observed (Photo Plate- IV). Dark Septate Endophytes (DSE) has formed septate hyphae and microsclerotia structure in cortical region of roots.

\section{Statistical Analysis of correlation studies}

Correlation studies between soil physicochemical properties, \% AMF colonization, \% DSE colonization and mean spore count from all sites of phase-I is presented in Table No.3.

In phase-I, \% AMF colonization was found to be positively correlated with Potassium, Copper and Zinc, likewise \% DSE colonization was found to be positively correlated with EC, Organic carbon, Nitrogen but \% AMF was found to be negatively correlated with $\mathrm{pH}$, Phosphorus, Potassium, Copper and Zinc. AMF spore count was found to be positively correlated with $\mathrm{pH}$ and Potassium but negatively correlated to EC, organic carbon, nitrogen, Phosphorus, Copper, Zinc, \% AMF and \% DSE.

In the present investigation, AMF \% root colonization were in between 1.25 (Coix aquatica) to $86.53 \%$ (Rottboella cochinchinensis); Root length with arbuscule ranged from 0 (in 15 grasses) to $53.33 \%$ (Spodiopogon rhizophorus); Root length with vesicle ranged from $O$ ( in 6 grasses) to $34.11 \%$ (Dichanthium pertusum), root length with AMF hyphae ranged from 0 (in 3 grasses) to $71.78 \%$ (Rottboella cochinchinensis); root length with hyphal coils ranged from 0 (in 35 grasses) to $12.22 \%$ (Eleusine indica). Whereas the DSE colonization in roots were in the range of 0 (in 10 grasses) to $38.90 \%$ (Arthrason lanceolatus). Root length with DSE hypha ranged from 0 (in 10 grasses) to 38.90\% (Arthrason lanceolatus); root length with microsclerotia ranged from 0 (in 60 grasses) to $2.43 \%$ (Pseudanthistiria umbellata). Table No.4.

\section{DISCUSSION}

The diversity of AM fungal species in Melghat forest associated with grass species was quite more than that of AM species reported by previous investigators. Choudhary et al., (2010) obtained 18 species belonging to 4 genera from marshy and shoreline vegetation of deeper beel Ramsar site of Assam, whereas Sathiyadash et al., (2010) reported only 11 species belonging to 3 genera from rhizospheric soil of south Indian grasses of Western Ghats. Chaudhry et al., (2006) was also isolated only 12 AMF species belonging to 3 genera from rhizospheric soils of perennial grasses from Cholistan desert, Pakistan. Thus, it can be said that the Melghat forest has more diversity of AMF species in compare to other studied area of the world and India.

Anjum et al., (2006) in their correlation studies reported that $\%$ mycelia and vesicular infection and number of vesicles were negatively correlated with all root and shoot growth parameters. Similarly, it was also reported by Baylis (1974) and Janos (1980).

\section{CONCLUSION}

The present investigation, moderate to very good AMF association along with DSE in different grasses were traced out. It can also make emphasis on the fact that mycorrhizal and DSE symbiosis was controlled by various edaphic factors. Moderate to high level of AMF colonization was an indication of better hyphae and root contact amongst different grasses of monocot plant species for increased benefits of AMF symbiosis and better adaptation to soil. Though there was less number of viable AMF spores in the rhizosphere soil of grasses there was high biodiversity of AM fungal species in the Melghat forest in comparison to previous studies on grasses.

From the present studies, it can be concluded that AMF diversity was high in compared to other regions of world. Glomus was recovered as the most dominant genus throughout the forest. An expanded AMF study from Melghat forest may be needed to determine relationships between AMF and DSE colonization. With the proper knowledge of mycorrhizal diversity in the rhizosphere of grasses, we can ensure better mycorrhizal inoculation programmes for sustainable availability of grass resources.

The selection of native dominant AMF, mass multiplication and its incorporation as biofertilizer is an important need for future technical development, restoration of burnt and destroyed grasses in the long-term sustenance of forest ecosystem in view to safeguarding the existence of wild animal life.

\section{ACKNOWLEDGEMENT}

The authors are grateful to the University Grants Commission, New Delhi for financial assistance.

\section{REFERENCES}

Anjum T, A. Javaid and Shah MBM (2006). Correlation between Plant Growth and arbuscular mycorrhizal colonization in some rainy season grasses. Pak J Bot 38(3):843-849.

Bagyraj D. J, V.S. Mehrotra and Suresh C.K. (2002). Vesicular-arbuscular mycorrhizal biofertilizer for tropical forest plants. In: Biotechnology of Biofertilizers pp. 375 Kluwer Academic Publishers, Dordrecht, The Netherlands.

Baylis, GTS (1974). The evolutionary significance of phycomycetous mycorrhizas. In: Mechanisms of Regulation of Plant Growth R. Soc. N. Z. Bull. No. Appl. 10:411-437.

Bellgard, S. E. (1993). The topsoil as the major store of the propagules of vesicular-arbuscular mycorrhizal fungi in southeast Australian sandstone soils. Mycorrhiza 3:19-24. https://doi.org/10.1007/bf00213463 
Bloemberg, G.V. and Lugtenberg B.J. (2001). Molecular basis of plant growth promotion and biocontrol by rhizobacteria. Curr Opin Plant Biol 4: 343-350. https://doi.org/10.1016/s1369-5266(00)00183-7

Brundrett, M. C. (1991). Mycorrhizas in natural ecosystems In Mac Fayden, M. Begon and A.H. Fitter (eds). Advances in Ecological Research Academic Press, London. p 171-133.

Chaudhry, M.S., F.H. Nasim and Khan, A. G. (2006). Mycorrhizas in the Perennial Grasses of Cholistan Desert, Pakistan. International Journal of Botany 2:210-218. https://doi.org/10.3923/ijb.2006.210.218

Choudhury, B., Kalita M.C. and Azad P. (2010). Distribution of arbuscular mycorrhizal fungi in marshy and shoreline vegetation of Deeper Beel Ramsar Site of Assam, India. World J Microbial Biotechnol 26:19651971. https://doi.org/10.1007/s11274-010-0377-8

Gaur, A. and Adholeya A. (1994). Estimation of VAM fungal spores in soil, a modified method. Mycorrhiza News 6:10-11.

Gerdemann, J.W. and Nicolson T.H. (1963). Spores of mycorrhizal Endogone species extracted from soil by wet sieving and decanting. Trans Br Mycol Soc 46:235-244. https://doi.org/10.1016/s0007-1536(63)80079-0

Gould, F. W. (1968). Grass systematic. Mc Graw-Hill Book Company New York.

Hiltner, L.(1904). Uber neue Erfahrungenund Probleme auf dem Gebiete der Bodenbaketeriologie. Arbeiten der Deutschen Landwirtschaftgesellschaft 98:59-78.

Janos, D. P. (1980). Mycorrhizae influence tropical succession. Biotropica 12:56-64. https://doi.org/10.2307/2388157

Jeeva, S. S. Kiruba and R. C. Laloo, 2006. Weeds of Kanyakumari district and their value in rural life. Indian J Tradit knowledge 5(4):501-509.

Jumpponen, A. (2001) Dark Septate endophytes-are they mycorrhizal? Mycorrhiza 11:207-211. https://doi.org/10.1007/s005720100112

Mandyam, K. and Jumpponen A. (2005). Seeking the elusive function of the root-colonizing dark septate endophytic fungi. Stud Mycol 53:173-189. https://doi.org/10.3114/sim.53.1.173

Mandyam, K. and Jumpponen A. (2008). Seasonal and temporal dynamics of arbuscular mycorrhizal and dark septate endophytic fungi in a tallgrass prairie ecosystem are minimally affected by nitrogen enrichment. Mycorrhiza 18:145-155. https://doi.org/10.1007/s00572-008-0165-6

Mitra, S. and Mukherjee S. K. (2005). Ethnobotanical usages of grasses by the tribals of West Dinajpur district, West Bengal. Indian J Tradit knowledge 4(4):396-402.

Mosse, B.(1973). Advances in the study of vesicular-arbuscular mycorrhiza. Ann Rew Phytopath 11:171-196.

Mukherji, K. G. and Kapoor, A. (1986). Occurrence and importance of vesicular-arbuscular mycorrhizal fungi in semi-arid region of India. For. E col Manag 16:117-132

Rachel, E. K., Reddy S. R. and Reddy S. M. (1989). VA mycorrhizal colonization of different angiospermic plant species in the semi-arid soil of Andhra Pradesh. Acta Bot Indica 17:225-228.

Saini,M. L., P. Jaina and Joshi U. N. (2007). Morphological characteristics and Nutritive Value of some grass species in an arid ecosystem. Grass Forage Sci 62:104-108. https://doi.org/10.1111/j.1365-2494.2007.00563.x
Sathiyadash, K., T. Muthukumar and Uma E. (2010). Arbuscular mycorrhizal and dark septate endophyte fungal associations in South Indian grasses. Symbiosis, 52(1), 21-32. http://doi.org/10.1007/s13199-010$\underline{0096-9}$

Schenck, N. C. and Perez Y. (1990). Manual for identification of VA Mycorrhizal fungi, Edited by N C Schenck N C and Y Perez, Gainesville, Florida, USA: INVAM, University of Florida Symbiosis 3(2):249-254.

Schwab, S. and Reeves, F. B. (1981). The role of endomycorrhizae in revegetation practices in the semiarid west. III. Vertical distribution of VAmycorrhiza inoculums potential. Am J Bot 68:1293-1297. https://doi.org/10.1002/j.1537-2197.1981.tb07839.x

Skerman, P. J. and Riveros F. (1990). Tropical grasses Food and Agriculture Organization of the United Nations.

Stebbins, G. L. (1972). The evolution of the grass family. In: Yaunger UD, Mc Kell CM (eds) The biology and utilization of grasses. Academic Press New York and London.

Wardle, D. A., Bardgett, R. D., Klironomous, J.N., Setala H. van der Putten W. H. and Wall D. H. (2004). Ecological linkages between above ground and below ground biota. Science 304:1629-1633. https://doi.org/10.1126/science.1094875

Wilox, H. E. (1991). Mycorrhizae In: The plant root: The Hidden Half. (Eds, Y Waisel, A Eshel and U Kafkati). Marcel Dekker, New York. pp 731-765.

Website:

http://invam.caf.wvu.edu/myc.intor/Taxonomy/species.htm http://melghattiger.gov.in/ 
PHOTO PLATE - I

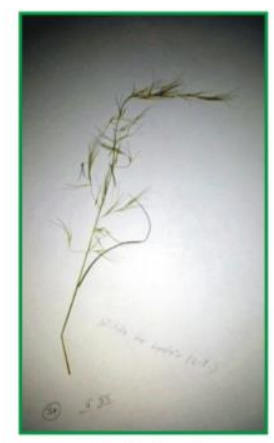

Aristida hystrix

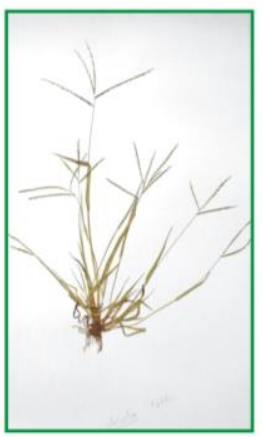

Digitaria stricta

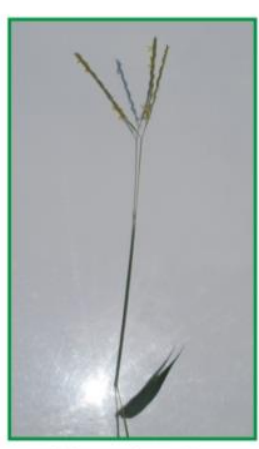

Arthraxon lanceolatus

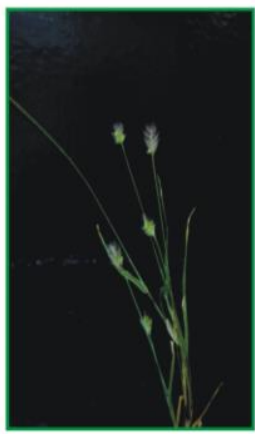

Setaria pumila

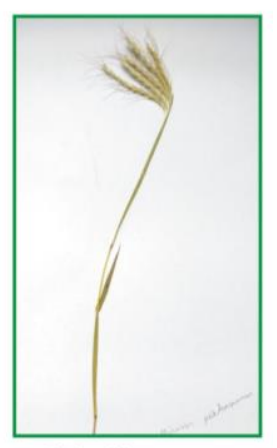

Dichanthium pertusum

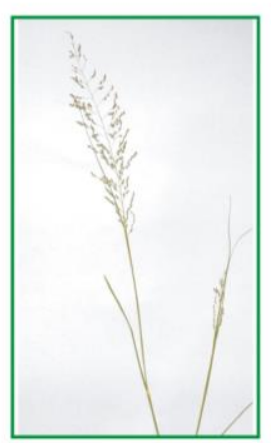

Sporobolus tenuissimus
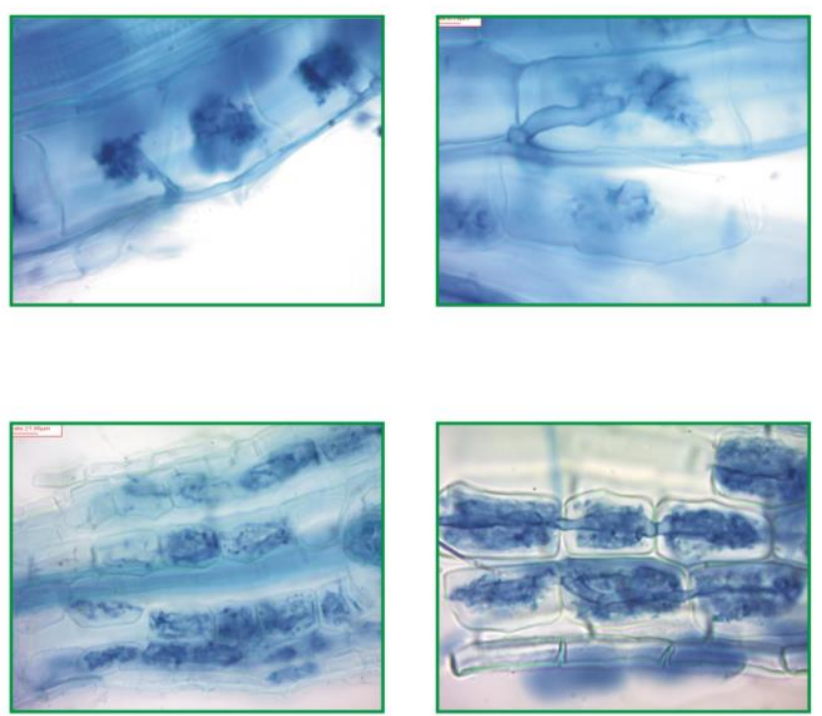

PHOTO PLATE - II

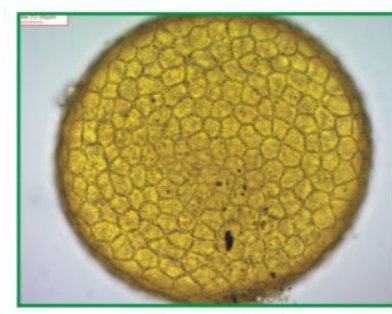

Acaulospora bireticulata

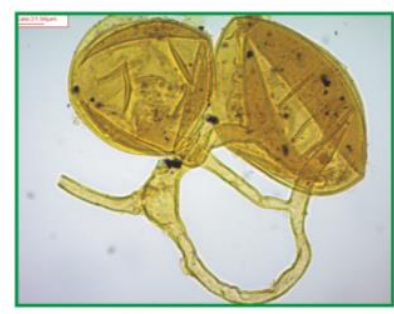

Glomus aggregatum

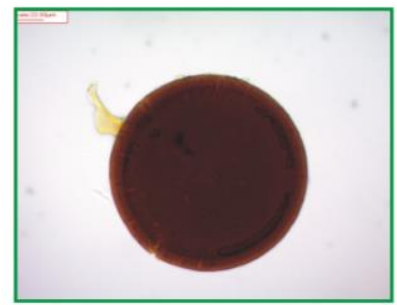

Glomus constrictum

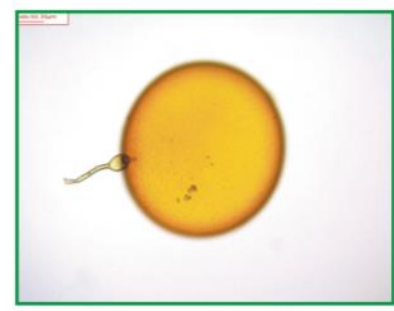

Gigaspora ramisporophora

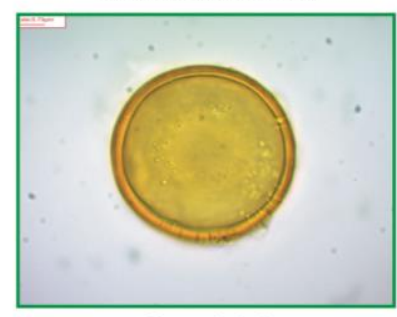

Glomus citricola

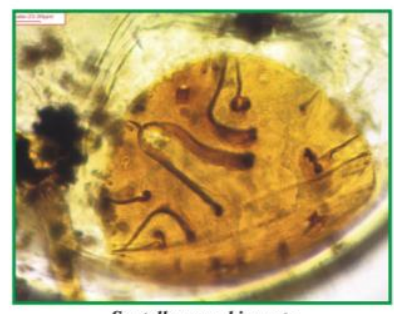

Scutellospora biornata

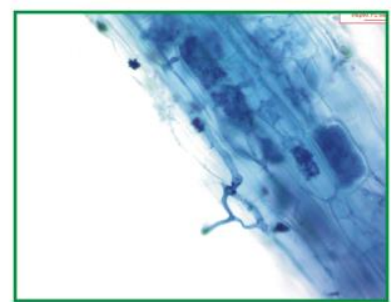

Hyphal penetration

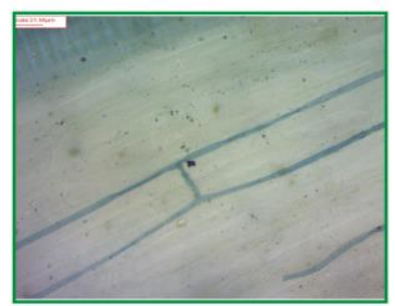

H-Connection

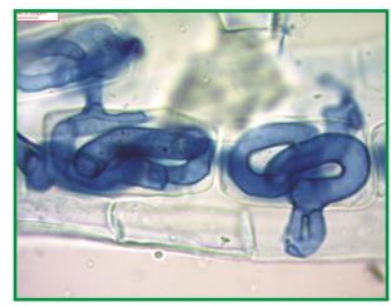

Hyphal coils
HOTO PLATE - II

Type of Arbuscule 


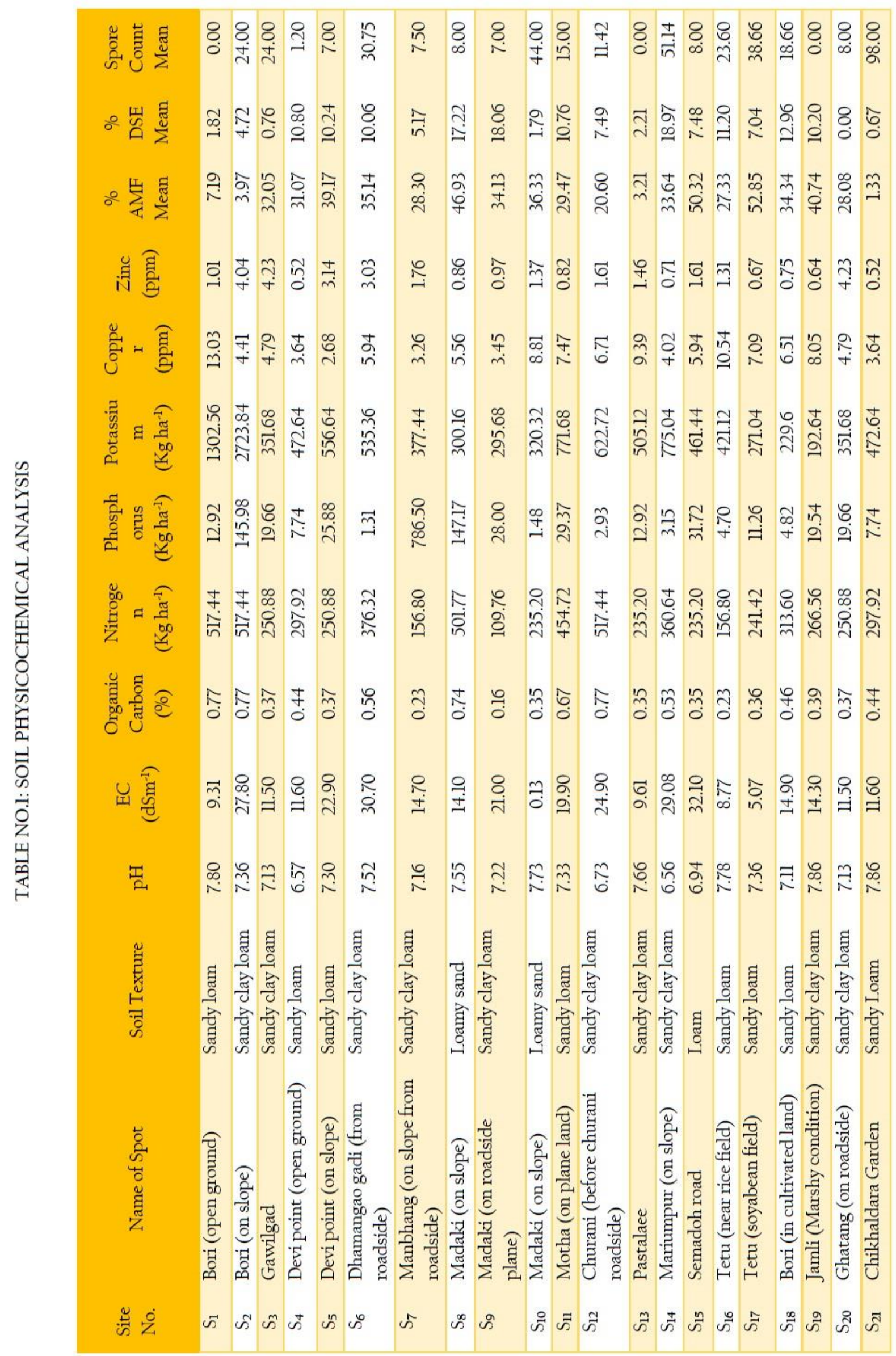




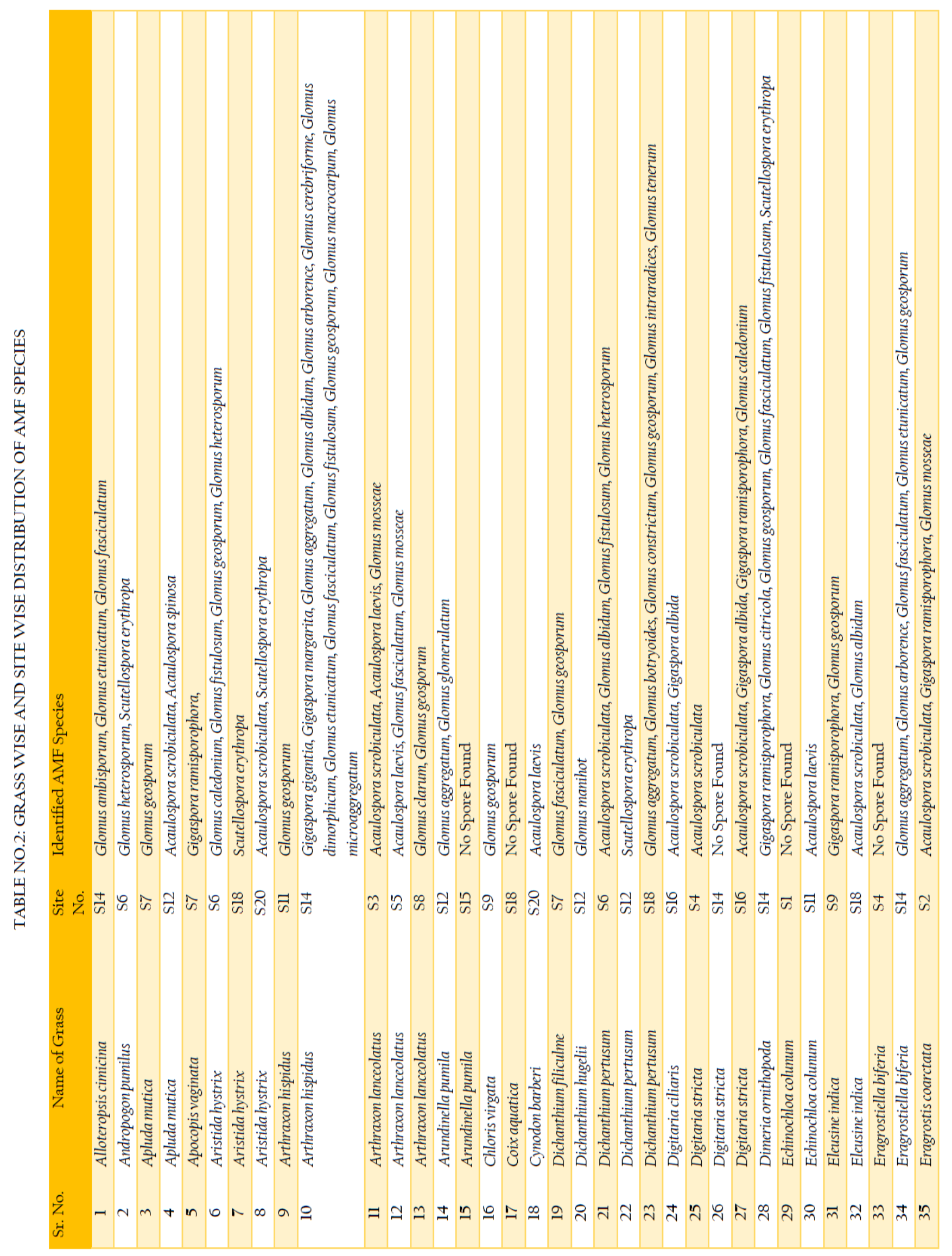




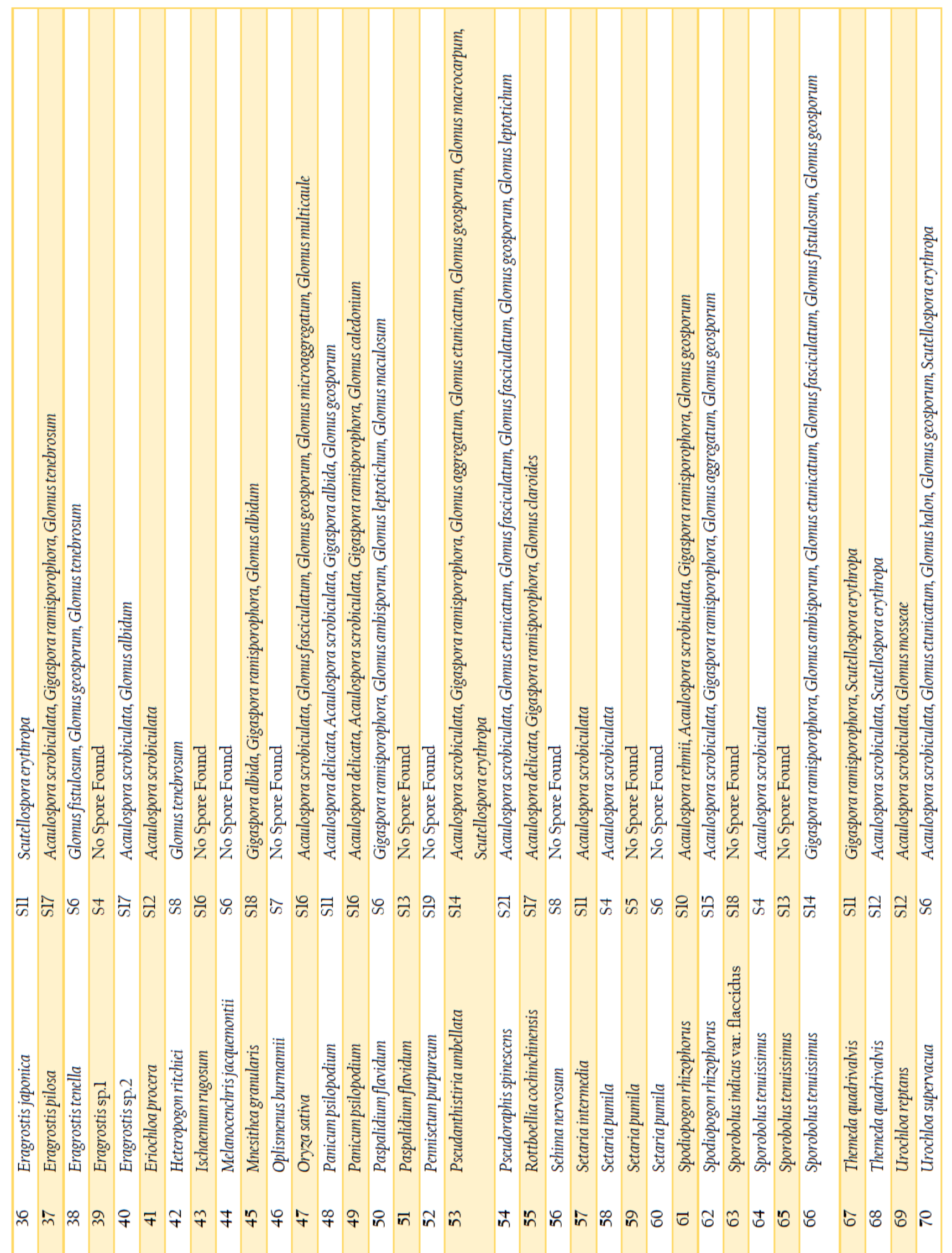




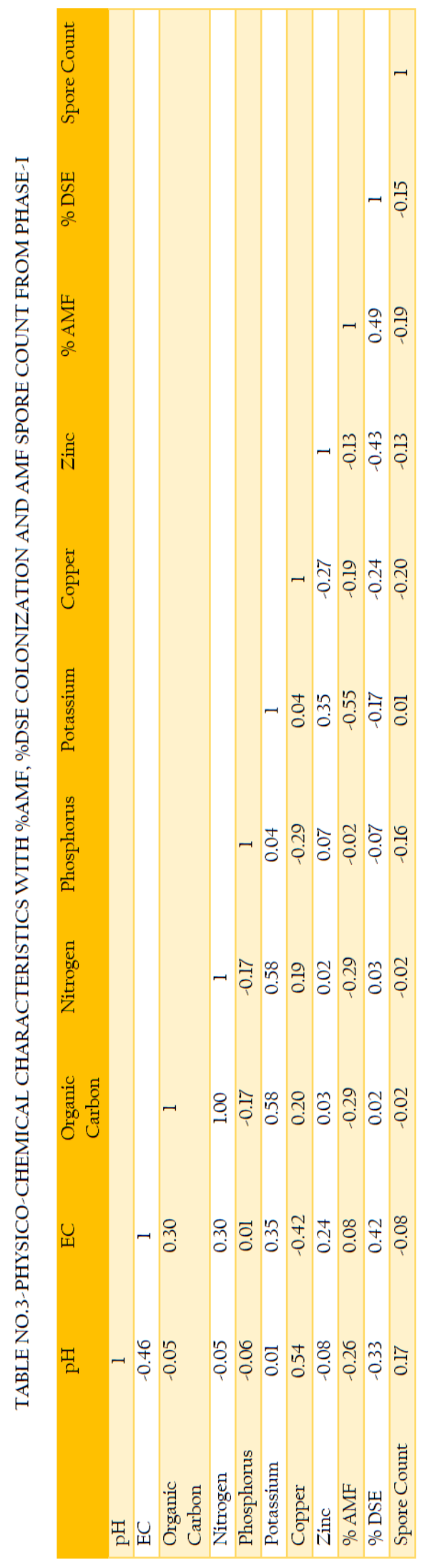

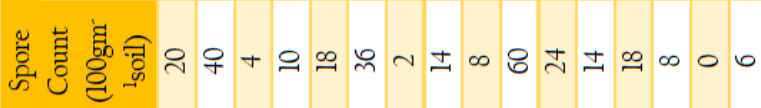

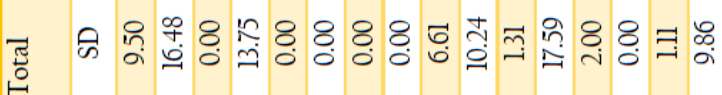

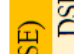

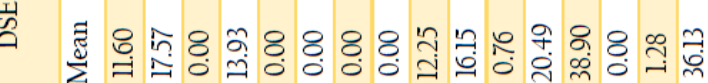

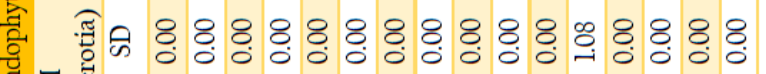
品 $\overline{2}$

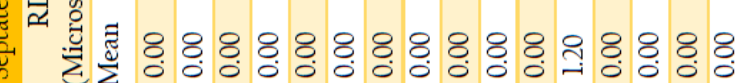

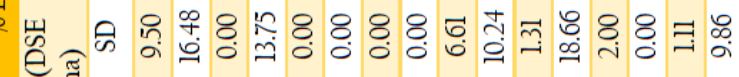

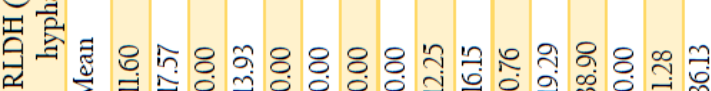

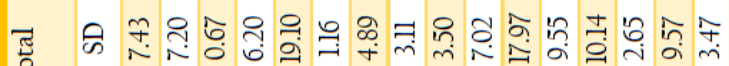
㟧

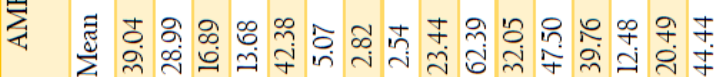

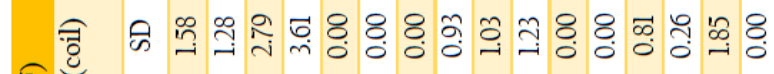

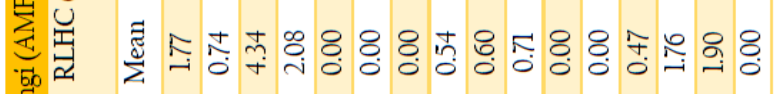

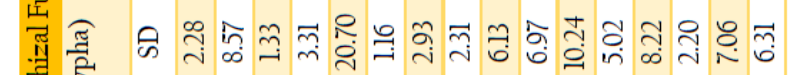

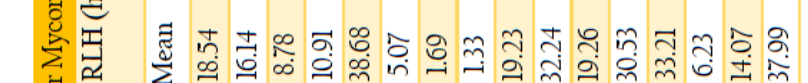

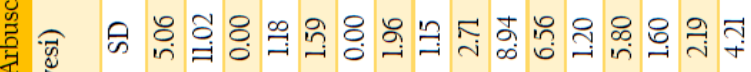

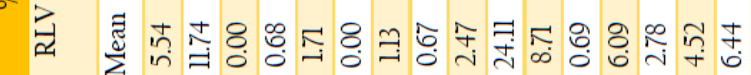

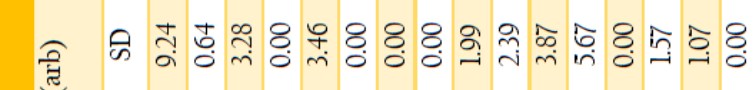

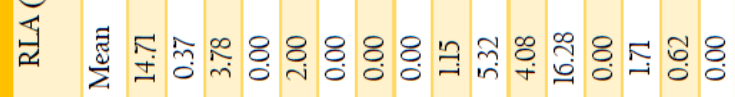

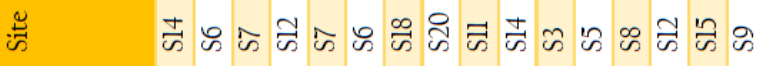

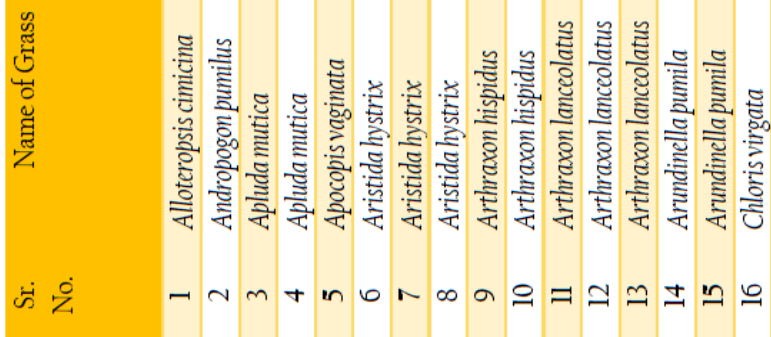




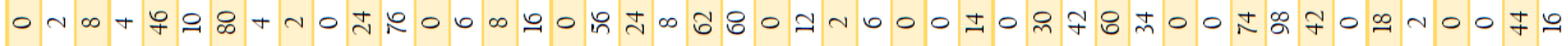

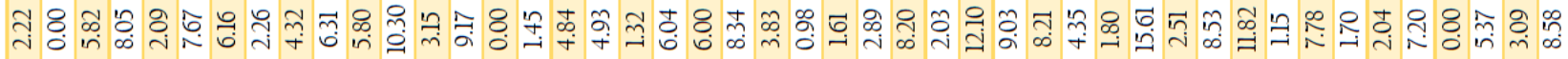

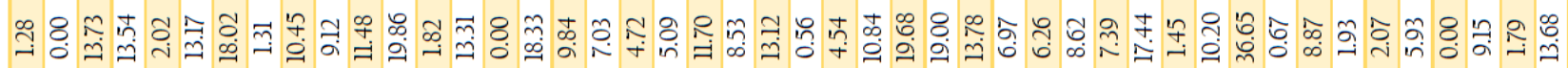

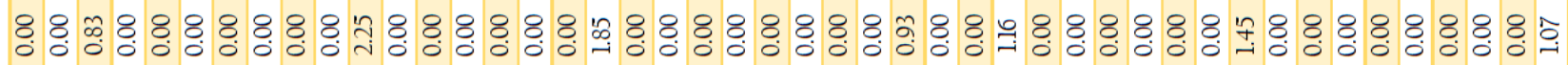

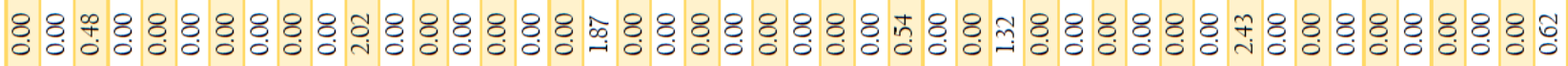
สี

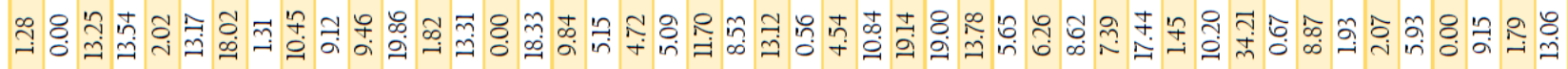

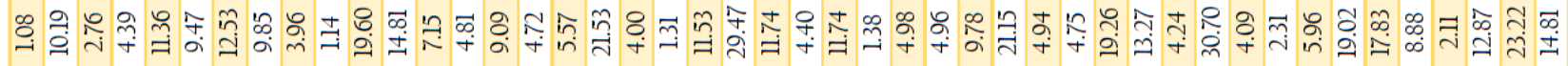

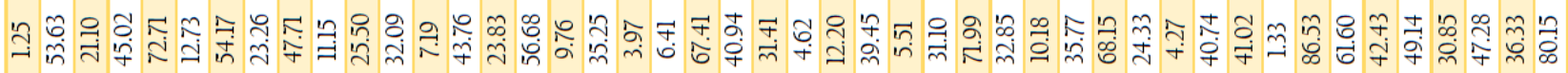

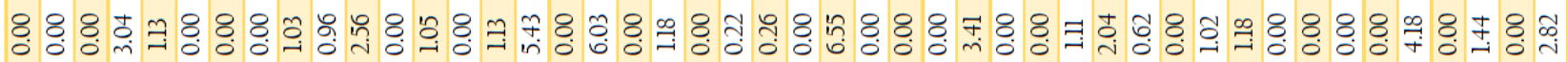
\&: \&

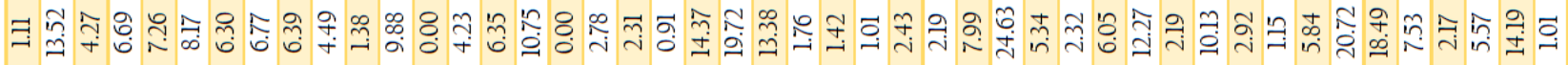

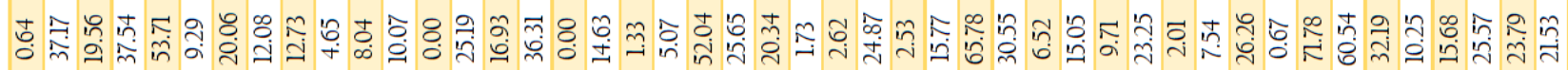

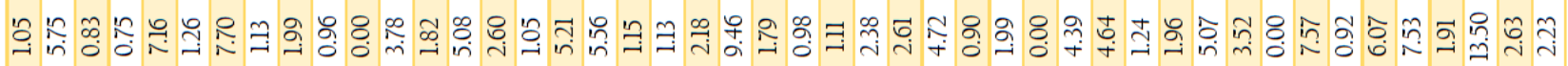

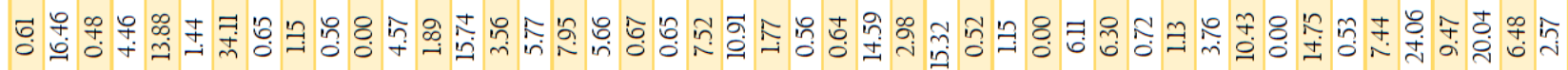
৪ : ৪ \& \&

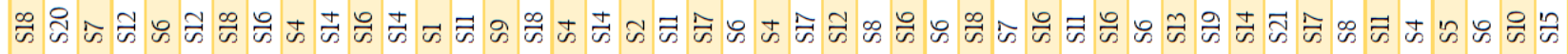

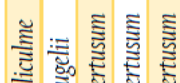

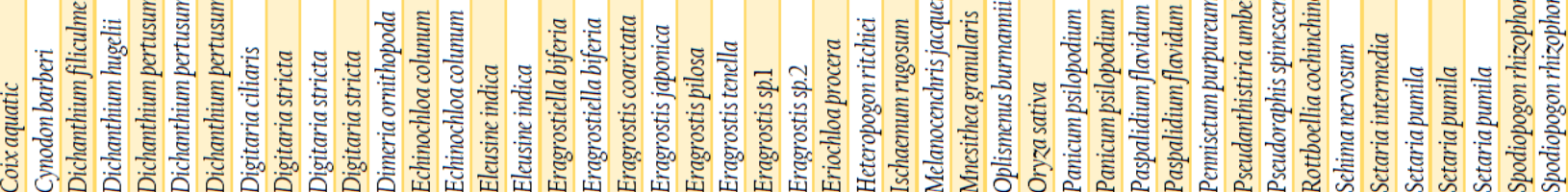

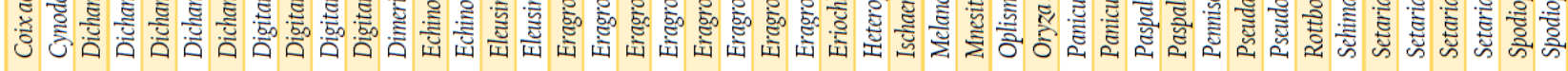

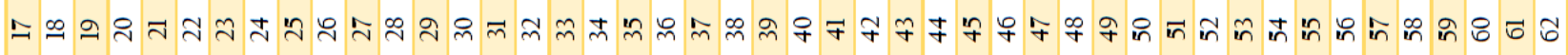




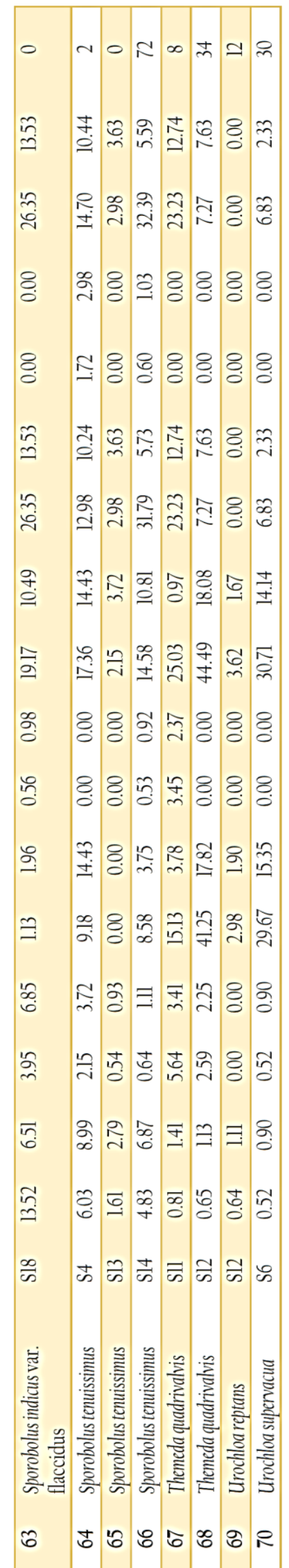

(O 2019| Published by Plantae Scientia 